\title{
Leaders' Support of Sustainable Innovation and Business Sustainability in Developing Countries: Evidence from Small and Medium Food Processing Enterprises
}

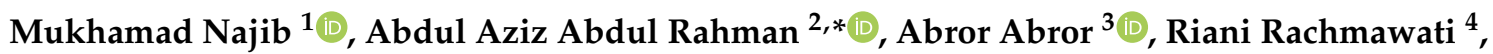 \\ Megawati Simanjuntak ${ }^{5}$, Prita Prasetya ${ }^{6}(\mathbb{D})$, Dwi Suhartanto ${ }^{7}$ and Farah Fahma ${ }^{8, *}$ \\ 1 Department of Management, IPB University, Bogor 16680, Indonesia; najib@apps.ipb.ac.id \\ 2 College of Business Administration, Kingdom University, Riffa 40434, Bahrain \\ 3 Department of Management, Universitas Negeri Padang, Padang 25132, Indonesia; abror094@fe.unp.ac.id \\ 4 Department of Management, Universitas Indonesia, Depok 10430, Indonesia; riani.rachmawati@ui.ac.id \\ 5 Department of Family and Consumer Science, IPB University, Bogor 16680, Indonesia; \\ mega_juntak@apps.ipb.ac.id \\ 6 School of Business and Economics, Universitas Prasetiya Mulya, Jakarta 12430, Indonesia; \\ prita.prasetya@pmbs.ac.id \\ 7 Department of Business Administration, Politeknik Negeri Bandung, Bandung 40012, Indonesia; \\ dwi.suhartanto@polban.ac.id \\ check for \\ updates \\ 8 Department of Agroindustrial Technology, IPB University, Bogor 16680, Indonesia \\ * Correspondence: a.abdulrahman@ku.edu.bh (A.A.A.R.); farah_fahma@apps.ipb.ac.id (F.F.)
}

Citation: Najib, M.; Abdul Rahman, A.A.; Abror, A.; Rachmawati, R.; Simanjuntak, M.; Prasetya, P.; Suhartanto, D.; Fahma, F. Leaders' Support of Sustainable Innovation and Business Sustainability in Developing Countries: Evidence from Small and Medium Food Processing Enterprises. Sustainability 2021, 13, 13091. https://doi.org/10.3390/ su132313091

Academic Editor: Carlos Rodríguez Monroy

Received: 24 October 2021

Accepted: 20 November 2021

Published: 26 November 2021

Publisher's Note: MDPI stays neutral with regard to jurisdictional claims in published maps and institutional affiliations.

Copyright: () 2021 by the authors. Licensee MDPI, Basel, Switzerland. This article is an open access article distributed under the terms and conditions of the Creative Commons Attribution (CC BY) license (https:// creativecommons.org/licenses/by/ $4.0 /)$.

\begin{abstract}
Business sustainability has become obligatory in small and medium enterprises (SMEs). To remain competitive and survive in the market, sustainable innovation is the key. However, SMEs, especially in food processing in emerging markets, still lack resources to become more innovative. The objective of the article is to analyze factors affecting sustainable innovation in food processing SMEs and their impact on business sustainability. Cross-sectional quantitative research builds on a sample of 157 owners of food processing SMEs in Indonesia. The results show that organizational sustainable innovation in food processing SMEs depends on employees' innovation potential and an organization's innovation culture; meanwhile, both variables are influenced by leaders' support of sustainable innovation. Promisingly, organizational sustainable innovation increases business sustainability. Thus, our research highlights the important role of leaders' support in achieving organizational sustainable innovation and, finally, long term business success. Furthermore, this study uncovers the underlying mediatory mechanisms, which deepen our theoretical understanding and guide practitioners with a concise and comprehensive framework for sustainable innovation in SMEs.
\end{abstract}

Keywords: sustainability; innovation; leader's support; employee capability; SMEs; developing countries

\section{Introduction}

Nowadays, many companies recognize that sustainable innovation plays a vital role in building a sustainable competitive advantage [1]. A total of $62 \%$ of executives consider a sustainability strategy necessary to be competitive today, and another $22 \%$ think it will be in the future [2]. Furthermore, a previous study mentioned that sustainable innovations, including product innovation and market innovation, are the source of value creation and essential for survival in the future competitive era [3]. However, innovation should not only help increase competitive advantage but must also be able to protect the environment and improve social welfare [4]. Therefore, it is crucial to balance economic, environmental, and social dimensions for the sustainable development of the industry [5]. In line with this argument, sustainable innovation in a company, including SMEs, must lead to business sustainability, where businesses can respond to their short term financial needs without compromising their ability to meet their future needs [6]. 
SMEs significantly contribute to sustainable development goals' (SDGs) achievement by creating jobs, reducing poverty, and redistributing income, particularly in developing countries [7]. In Indonesia, for instance, SMEs number 64.2 million units and contribute $61.07 \%$ to the total gross domestic product (GDP). In addition, SMEs can absorb $97 \%$ of the total national workforce [8]. Besides their remarkable contribution to poverty reduction and SDGs in general, food processing SMEs should consider the sustainability issue in their business operation so that their contribution to environmental protection can be higher [9]. Additionally, from a marketing perspective, customers now have more concerns about sustainability in food processing products, especially in food packaging, food waste, recycling plastic, bottles and cans, and water and energy conservation [10].

Previous studies noted that food processing produces a large quantity of waste worldwide, and SMEs also create a large share of the waste in the environment $[11,12]$. Considering environmental footprint, SMEs are responsible for $\Omega$ significant carbon emissions $[13,14]$. A study in OECD countries estimated that SMEs contribute $60-70 \%$ to industrial pollution [15]. Therefore, to diminish the undesirable effect on the environment, SMEs should not focus just on operational performance, but also on integrating sustainability practices. In this sense, the adoption of sustainable innovation has become a necessity for food processing SMEs today. SMEs with a good awareness of sustainability practices would obtain a competitive advantage sustainably [16-18]. However, the implementation of sustainable innovation practices is not perceived as a promising business strategy by SMEs owners [19]. Furthermore, research related to the impact of sustainable innovation on the business sustainability of SMEs is still limited [20].

Sustainable innovation, as defined by Kneipp et al. [21], is the creation of something new that improves performance in the three dimensions: the social, environmental and economic. Sustainable innovation could be studied based on three primary perspectives: internal managerial, external relational, and performance evaluation [22]. At the level of SMEs, there are many internal managerial obstacles when SMEs try to practice sustainable innovation [23,24]. Therefore, a study focusing on the internal factors that affect sustainable innovation and business sustainability is important. Moreover, past literature mentioned that internal capacity enables SMEs to unlock the barrier and practice of innovation, as it is related to their ability to absorb new knowledge, leaders' commitment, and human capital readiness [25-27]. Previous research conducted by Iqbal et al. [28] confirms that sustainable leaders indirectly influence environmental performance through environmental innovation. Nevertheless, research related to the organizational sustainable innovation model that considers the leader's support of sustainable innovation, employees' innovation potential capability and organizational innovation culture as determinant factors comprehensively are still rare, especially in the context of SMEs.

It is vital to analyze the impact of the organizational sustainable innovation model developed in this study on business sustainability, since sustainable innovation practices in the context of SMEs will reduce environmental damage, improve the quality of life, and increase the economic development of the country [5,29]. Therefore, this study will provide insight into enhancing the business sustainability of food processing SMEs through sustainable innovation practices. Based on the research gap, as explained above, this study aims to analyze factors affecting sustainable innovation and evaluate its impact on business sustainability. Specifically, this study aims: (1) to describe organizational sustainable innovation practice in Indonesian food processing SMEs, (2) to analyze the direct effect of leaders' support of sustainable innovation, employees' innovation potential capability and organizational innovation culture on organizational sustainable innovation, (3) to discover the impact of organizational sustainable innovations on business sustainability, and (4) to evaluate the indirect effect of a leader's support of sustainable innovation on organizational sustainable innovation and business sustainability.

This research will have both theoretical and practical contributions. This study has revealed a more robust organizational sustainable innovation model in the food processing SMEs' context for theoretical contribution. It has also highlighted the significant impacts of 
a leader's support of sustainable innovation on employees' innovation potential capabilities and organizational innovation culture, which were neglected previously. For managerial implications, this study has contributed a method for the managers of SMEs to develop their organizational sustainable innovation by giving more attention to a leader's support to sustainable innovation, employees' innovation potential capability and organizational innovation culture. This study also contributes to decision makers, such as the government, in arranging a sustainable strategy for SMEs in Indonesia.

\section{Literature Review}

Tello and Yoon [30] defined sustainable innovation as the development of new products, processes, services and technologies that contribute to the development and wellbeing of human needs and institutions while respecting natural resources and regeneration. In line with this, Schiederig et al. [31] defined sustainable innovation as an extension of the concept of green innovation or environmentally friendly innovation by adding social orientation and the needs of future generations. Wang et al. [32] defined sustainable innovation as an innovation intended for safe future generations and a firm's sustainability. Based on such literature, the applicable definition of sustainable innovation used in this study is an innovation that maintains a balance between economic, environmental and social orientations.

In the context of a food processing company, sustainable innovation becomes more important, particularly to respond to environmental regulation and changing customer behavior. Concerning sustainable innovation, researchers argue that food processing should make changes in food procurement, service provision, waste management, energy efficiency and water conservation $[33,34]$. Companies that adopted sustainable innovations have decided to implement sustainability practices or products to alleviate their adverse environmental, social, and economic impacts [35].

Sustainable innovation could be studied from internal and external perspectives [22]. According to dynamic capabilities and resource based view theories, organizational resources (including tangible and intangible resources) and capability influence innovation and business performance [36-38]. However, from the perspective of SMEs, internal factors play a more substantial role in developing innovation [39]. Several authors [40,41] have analyzed how managerial capabilities can help companies respond to ongoing changes in the business environment and improve their competitive advantage. This study argues that managerial capability in this study context is related to the role of a leader in supporting sustainable innovation, employee capability and innovation culture. Therefore, this study will evaluate those variables concerning sustainable innovation and business sustainability in the food processing SMEs context.

\subsection{Leader's Support of Sustainable Innovation}

Leader refers to the actor who leads in an organization; meanwhile, leadership is an influencing process from a leader to a member in an organization to achieve a common goal [42]. Previous studies have shown the critical role of a leader in influencing an employee's attitude and behavior [26]. One of the vital roles of a leader is enhancing their employees' morale and motivating them to achieve their best performance and continuously improve their employees' capability [43]. In other words, the role of the leader is to provide support, in this case, to support sustainable innovation.

Employee capability itself can be defined as the ability of employees to properly exploit the resources they have, including skills, knowledge, and experience. Capabilities create the basic framework for developing individual skills so that employees can perform. Therefore, the concept of capability implies an interactive process of coproduction, engaging a person and her or his environment [44]. The role of a leader in improving employees' innovation potential capability can be completed by managing interactions, showing support as a leader, displaying organizational support and so forth [45]. This study argues that a 
leader's support of sustainable innovation will lead employees to improve their knowledge and sustainability skills.

A leader's support of sustainable innovation is not only as a motivator who encourages an employee to become more innovative, but also promotes a creative environment and climate of confidence, such as facilitated knowledge sharing or hearing employee voices, that leads to innovation culture [45]. Concerning the culture of organizational innovation, a leader's support influences the innovation ecosystem applied in organizations, which leads to employee creativity and innovation [43,46]. Moreover, Waite [42] confirmed that leadership is one of the significant factors that affects innovation in an organization. The leader's support is to help the organization members to define and shape work environments that contribute to innovation. Moreover, the leader also has the power to create and manage an organizational culture that promotes innovation. Based on previous literature, this study proposed hypotheses as follows:

Hypothesis 1 (H1). Leaders' support of sustainable innovation influences employees' innovation potential capability.

Hypothesis 2 (H2). Leaders' support of sustainable innovation influences organizational innovation culture.

\subsection{Factors Affecting Organizational Sustainable Innovation}

Fostering innovation in companies needs competencies and capabilities and strategy and culture [47]. Competences and capabilities are more related to employees; meanwhile, the strategy and culture development for innovation is part of a leader's role. Research conducted by Waite [42] mentioned that the role of a leader is responsible for driving creativity and innovation in organizations. Furthermore, a leader concerned about sustainability will encourage their employees and organize their company to practice sustainability, such as developing new environmentally friendly products. Therefore, a leader's support of sustainable innovation plays a vital role in ensuring sustainable innovation in an organization [48]. In this study, the following hypothesis is proposed:

Hypothesis 3 (H3). Leaders' support of sustainable innovation influences organizational sustainable innovation.

Employees have hidden abilities for innovation [49], which can be made visible, recognized, and exploited to benefit both the firm and its employees. In terms of the resource based view, these hidden abilities can be understood as an existing, albeit underutilized, resource. Such an approach implies that employees at all levels of the organization are perceived as innovation capital or innovation assets. Since innovation becomes essential for competition, the competitive advantage of SMEs could be built through their employees' creative potential to develop innovative products for their niche markets [50]. Furthermore, previous studies revealed that retaining capable employees is critical for innovation [51,52]. In this sense, employees capable of innovation and environmental issues are needed to develop sustainable innovation. Therefore, employees' innovation potential capabilities, characterized by knowledge and skill, are the key enablers of innovation [50]. Hence, this study posits a hypothesis as follow:

Hypothesis 4 (H4). Employees' innovation potential capability influences organizational sustainable innovation.

Culture has an essential role in determining creative behavior. An innovative organizational culture, such as a creative organization culture, can provide the opportunity to initiate sustainable innovation [53]. Innovation culture can be defined as an entrepreneurial venture that facilitates activities including, but not limited to, the pursuit of novel products, services, and production processes [50,54,55]. Meanwhile, El Harbi et al. [47] defined 
innovation culture as a firm's social and cognitive environment, the shared view of reality, and the collective belief and value systems reflected in a consistent pattern of behaviors among participants. According to Higgins and Allastar [56], an organizational innovation culture represents an intangible resource that contributes to increased levels of innovation. Thus, an organizational innovation culture provides a way of thinking and a way of acting that aids innovation. Several previous researchers noted that organizational innovation culture could be a significant driver for sustainable innovation $[47,51]$.

Hypothesis 5 (H5). Organizational innovation culture influences organizational sustainable innovation.

\subsection{Factors Affecting Business Sustainability}

Business sustainability is a company's strategy to prioritize its efforts on long term business goals $[29,57]$. The sustainability of a business is mainly influenced by its ability to face competitive pressures and adapt to rapid environmental changes, such as consumers' preferences $[58,59]$. In the context of SMEs, business sustainability relates to business performance. Hence, business performance may become one of the business sustainability indicators. Besides, business sustainability is indicated by three orientations, including ecology, economy and social orientation. Therefore, this study may improve business performance as indicators of business sustainability besides other indicators, i.e., ecology and social performance.

The sustainability of a business depends on the skill and ability of employees working in the organization. According to Ullah et al. [60], capable employees (capable of ensuring environmental sustainability through the company's manufacturing practices) tend to contribute to business sustainability. Past research had also explored the relationship between employee capability and business performance. Wei et al. [51] confirm that employee capability has a positive link to performance. Moreover, research conducted by Bag and Gupta [61] in the Chinese manufacturing industry found that employee capability in sustainability practices has a positive influence on business performance. Research conducted by Iqbal [62] mentioned that green human resource management had a moderating role on environmental sustainability. From the perspective of business sustainability, research confirms that green human capital has a positive and significant effect on business sustainability [60]. In addition, a previous study mentioned that employee capability in environmental concerns plays a crucial role in organizational sustainability [63]. Therefore, this study proposes the following hypothesis:

Hypothesis 6 (H6). Employees' innovation potential capability influences business sustainability.

Creativity and innovative thinking play an essential role in improving an organization's productivity, processes, and services. They also encourage innovation, driven by the organization's culture [64]. The constructive culture of a firm increases cooperation within organizational units in firms. In the framework of innovation culture, employees are encouraged to share their ideas and solve organizational problems together. The culture that facilitates employees to express their ideas freely, share knowledge, and learn together becomes an innovative friendly culture. An organizational innovation culture will develop employees to become alert, creative, and innovative, and it can indirectly enhance a firm's performance [50]. Previous studies also noted that an organizational innovation culture has a positive influence on organizational performance [55]. In addition, another previous study indicated that, compared to a non-innovating firm, innovation activity has positive effects on firms' productivity [65]. Consequently, this study proposes a hypothesis as follows:

Hypothesis 7 (H7). Organizational innovation culture influences business sustainability.

Several previous studies [66,67] highlight the importance of innovation as a driver of business performance. Previous research also found that the practice of innovation is the 
driver of business performance in the context of SMEs restaurants [29]. Sustainable innovation reflected by product and process innovations generates success in terms of sales and profit [2]. Furthermore, researchers believed that sustainable innovation positively impacts business performance [39] and ecology and social performance [4]. However, the effect of sustainable innovations on business performance is still unclear. Sustainable innovation pushed by the government or environmental regulation may impose additional costs and decrease profits [68]. For example, a palm oil company wishing to adopt sustainable palm oil practices found that the costs incurred were higher than the potential revenue $[69,70]$.

Furthermore, past research noted that green innovation generated by the strictness of environmental regulations harmed business performance [71]. Therefore, it means danger for business sustainability from the economic perspective. Based on the literature review above, this study posits the following hypotheses:

Hypothesis 8 (H8). Organizational sustainable innovation influences business sustainability.

\subsection{The Indirect Effect of Leader's Support on Business Sustainability}

Business sustainability needs leaders who have a commitment to implementing sustainable practices in their organization [72]. Several studies [43-45] mentioned that the role of leader may facilitate conducive environment for innovation, workforce development, and encourage them to improve their knowledge and creativity. The role of leader is also important in establishing an organizational innovation culture [45]. Further, research conducted by Iqbal et al. [28] noted that the role of the leader in environmental performance is mediated by environmental innovation. This study establishes the following hypotheses:

Hypothesis 9a (H9a). Leaders' support of sustainable innovation influences business sustainability indirectly through sustainable innovation.

Hypothesis $9 \mathbf{b}(\mathbf{H 9 b})$. Leaders' support of sustainable innovation influences business sustainability indirectly through employees' innovation potential capability.

Hypothesis 9c (H9c). Leaders' support of sustainable innovation influences business sustainability indirectly through organizational innovation culture.

A review of the organizational innovation literature $[22,23,28]$ clarifies that variables such as a leader's support of sustainable innovation, employees' innovation potential capability and organizational innovation culture positively influence sustainable innovation. Therefore, this study argues that a leader with a sustainable orientation, employees capable in sustainability issues, and organizational innovation culture in SMEs will positively impact sustainable innovation. Furthermore, organizational sustainable innovation, together with employees' innovation potential capability and organizational innovation culture, would be a predictor of business sustainability. Consequently, this study proposes an initial organizational sustainable innovation and business sustainability model, as seen in Figure 1. 


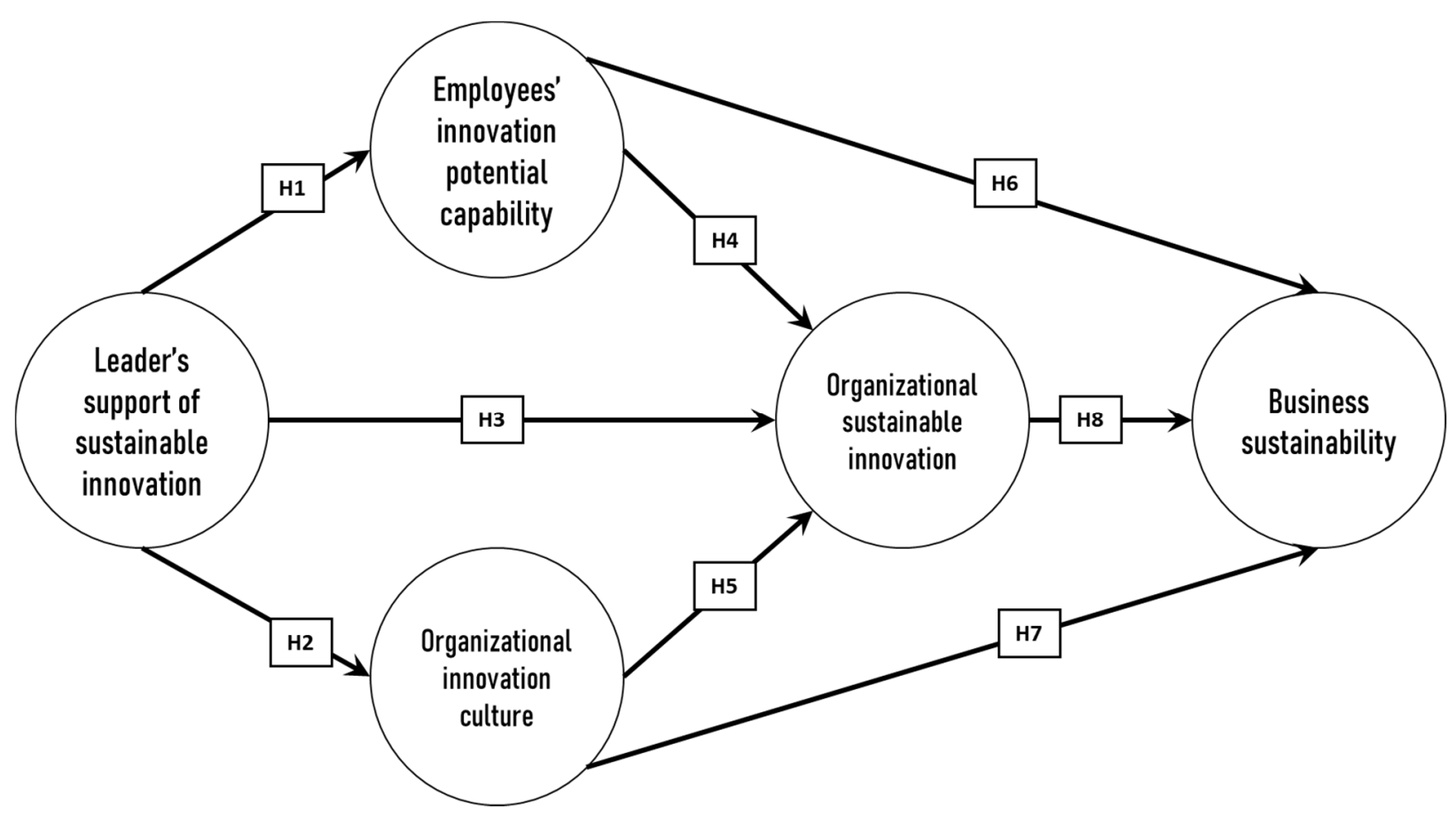

Figure 1. The initial model of sustainable innovation and business sustainability.

\section{Methods}

Our objective is to analyze factors affecting organizational sustainable innovation and evaluate its impact on business sustainability in Indonesian food processing SMEs, as an emerging market country. This study is not developing or testing theory, but assessing existing concepts' explanatory power and relevance in a different context. Therefore, this research tries to evaluate a leader's support of sustainable innovation, employees' innovation potential capability, and organizational innovation culture concerning sustainable innovation and business sustainability in the context of food processing SMEs in an emerging market country, since this kind of study is still rare.

\subsection{Data Collection}

A cross-sectional single post-test design was used to study the population of food processing SMEs. The unit of analysis was SME, whereas the unit of observation was the SME's owner or manager. Primary data was collected by surveying owners or managers of food processing SME in Jakarta and the surrounding area in September 2019-February 2020. As the capital city of Indonesia and its surrounding areas, such as Bogor, Depok and Tangerang district, Jakarta has many SMEs, particularly in the food processing sector. Samples were selected based on the purposive sampling technique with the following criteria: (1) SMEs engaged in the food processing sector, (2) have been operating for more than two years, (3) respondents were owners or managers who understand their business comprehensively. The criteria for SMEs used classification was based on the Indonesian Statistics Agency (BPS). SMEs were divided based on the number of workers, where small enterprises have fewer than 20 workers, and medium enterprises have 21-99 workers. The number of samples in this study was determined based on the rule of thumb in SEM analysis, a minimum of 100 samples or 5-10 times the number of indicator variables [73,74]. As the number of variable indicators was 24 , the sample collected can be between 120 and 240 samples. In this study, 180 respondents had been collected; however, after preliminary checks such as questionnaire completion, only 157 responses $(87.2 \%)$ were analyzed. 


\subsection{Measurement}

The research questionnaire was developed to enable respondents to respond to research questions. The closed list of questions was provided using a 5 Likert's scales, so that the respondent only had to answer 1 for strongly disagreed and 5 for strongly agreed for each question. Each variable to be tested in this study was measured by an indicator variable adapted from previous studies. The adaptation process of existing measurement tools is based on consultation with five experts: two marketing experts, one organizational and behavioral expert, one environmental expert and one SME development strategy expert. Consultation with experts in the field is also essential to ensure content validity and face validity. The measurement items for each variable can be seen in Table 1 .

Table 1. Measurement items.

\begin{tabular}{ccc}
\hline Construct & Measurement Items & Sources \\
\hline Leader's support of sustainable innovation & Four items & {$[48,75]$} \\
Employees' innovation potential capability & Five items & {$[76,77]$} \\
Organizational innovation culture & Five items & {$[78,79]$} \\
Organizational sustainable Innovation & Three items & {$[21,80]$} \\
Business sustainability & Six items & {$[17,21,39]$} \\
\hline
\end{tabular}

\subsection{Data Analysis}

The data were analyzed using the structural equation model (SEM). The use of SEM made it possible to strengthen the existence of a perspective that was developed based on previous research, since this analysis was characterized as a confirmatory analysis. In the SEM analysis, factor analysis and regression analysis can be conducted simultaneously so that the relationship between latent variables can be analyzed accurately and between latent variables and their observed variables. Two models will be analyzed in SEM, namely, the measurement and structural models [73,74]. The measurement model was used to analyze the relationship between observed variables and their latent variables; meanwhile, the structural model was used to analyze relationships among exogenous latent variables and endogenous latent variables. To analyze the explanatory power of the business sustainability model developed, this study used $R^{2}$ value. Statistical Package for the Social Sciences (SPSS 24) and Analysis of Moment Structures (AMOS 24) were employed for assessing the data gathered from the 157 respondents of SMEs' owners or managers.

\section{Results}

\subsection{Profile of Respondent}

This study reported the respondents' profiles based on demographic factors, including gender, age, income level, education, and business experience. Table 2 shows that most of the respondents were males $(72 \%)$. This is in line with the characteristic of small and medium businesses in Indonesia, which are majority owned or managed by males [59]. Furthermore, it was found that the highest number of respondents' age (36.9\%) ranged between 30 and 40 years, representing the business's maturity. In terms of education level, most respondents ( $42 \%$ ) graduated from senior high school; this is also typical of the owners of SMEs in Indonesia. Apart from formal education, all respondents have attended relevant training for business development (see Table 2). The three pieces of training that respondents mostly attended were managerial training $(97.5 \%)$, entrepreneurship training (77.1\%) and waste management and sanitation training (75.2\%). In terms of work experience, $52.2 \%$ of respondents had worked at other food companies for more than five years. This experience can be a sufficient provision to be able to manage the business better. 
Table 2. Profile of respondent.

\begin{tabular}{|c|c|c|c|}
\hline Characteristic & Criteria & Frequency $(N=157)$ & Percentage $(\%)$ \\
\hline \multirow{2}{*}{ Gender } & - $\quad$ Male & 113 & 72 \\
\hline & Female & 44 & 28 \\
\hline \multirow{4}{*}{ Age (years old) } & $<30$ & 54 & 34.4 \\
\hline & $-\quad 30-40$ & 58 & 36.9 \\
\hline & - $\quad 41-50$ & 27 & 17.2 \\
\hline & $>50$ & 18 & 11.5 \\
\hline \multirow{3}{*}{ Education level } & Junior high school or less & 38 & 24.2 \\
\hline & - Senior high school & 66 & 42.0 \\
\hline & - $\quad$ Bachelor or above & 53 & 33.8 \\
\hline \multirow{5}{*}{ Training * } & Entrepreneurship training & 121 & 77.1 \\
\hline & - $\quad$ Managerial training & 153 & 97.5 \\
\hline & - $\quad$ New product development training & 97 & 61.8 \\
\hline & - Waste management and sanitation & 118 & 75.2 \\
\hline & - $\quad$ Others & 47 & 29.9 \\
\hline \multirow{3}{*}{ Experience as a worker in other food business } & More than five years & 62 & 39.5 \\
\hline & Less than five years & 82 & 52.2 \\
\hline & Never & 13 & 8.3 \\
\hline \multirow{4}{*}{ Location } & - Jakarta & 52 & 33.1 \\
\hline & - $\quad$ Bogor & 39 & 24.9 \\
\hline & Depok & 31 & 19.7 \\
\hline & Tangerang & 35 & 22.3 \\
\hline
\end{tabular}

* Respondent may answer more than one option.

\subsection{Business and Innovation Profile}

Table 3 shows the business and innovation profile. Regarding the number of workers, $48.4 \%$ of the SMEs employed between 10 and 20 people, and the rest (51.6\%) had between 21 and 99 employees. Based on the business category by Indonesian Statistic, the majority of respondents came from medium sized enterprises. Previous study in Indonesia found that medium sized businesses are more innovative than small businesses [4]. Most respondents have operated their business between 3 and 10 years $(65 \%)$ in terms of length of operation. It is a sufficient time to evaluate the factors that affect business sustainability, as the companies surveyed have proven to survive more than three years. Research conducted by Higdon [81] shows that in the context of a coffee shop, a business that can go through the first three years of the pioneering and introductory phases has the potential to build a sustainable business.

Table 3. Business profile and innovation.

\begin{tabular}{|c|c|c|c|}
\hline Characteristic & Criteria & $\begin{array}{c}\text { Frequency } \\
(\mathrm{N}=157)\end{array}$ & $\begin{array}{c}\text { Percentage } \\
(\%)\end{array}$ \\
\hline \multirow{3}{*}{ Number of Workers } & $10-20$ & 76 & 48.4 \\
\hline & $-\quad 21-50$ & 52 & 33.1 \\
\hline & $-\quad 51-99$ & 29 & 18.5 \\
\hline \multirow{4}{*}{ Length of Operation (years): } & $<3$ & 25 & 15.9 \\
\hline & $-\quad 3-5$ & 59 & 37.6 \\
\hline & $-\quad 5-10$ & 43 & 27.4 \\
\hline & $>10$ & 30 & 19.1 \\
\hline \multirow{3}{*}{ Sales Value (IDR) } & $<25$ million/month & 27 & 17.2 \\
\hline & 25-50 million/month & 89 & 56.7 \\
\hline & $>50$ million/month & 41 & 26.1 \\
\hline \multirow{4}{*}{ Types of Process Innovation * } & - $\quad$ Processing waste properly (reduce, reuse, recycle) & 118 & 75.2 \\
\hline & - $\quad$ Minimizing electricity & 157 & 100 \\
\hline & - $\quad$ Using clean energy (gas, solar cell, etc.) & 125 & 79.6 \\
\hline & Avoiding the use of plastic products & 157 & 100 \\
\hline \multirow{3}{*}{ Types of Product Innovation * } & Using organic raw material for new product & 79 & 50.3 \\
\hline & Avoiding/minimizing the use of chemicals additive & 116 & 73.8 \\
\hline & Using eco friendly packaging & 157 & 100 \\
\hline
\end{tabular}


Table 3. Cont

\begin{tabular}{|c|c|c|c|}
\hline Characteristic & Criteria & $\begin{array}{c}\text { Frequency } \\
(\mathbf{N}=157)\end{array}$ & $\begin{array}{c}\text { Percentage } \\
(\%)\end{array}$ \\
\hline \multirow{4}{*}{ Reason for sustainable Innovation * } & Want to protect the environment & 145 & 92.4 \\
\hline & - $\quad$ Because of government regulation & 121 & 77.1 \\
\hline & - Competitive pressure & 98 & 61.8 \\
\hline & - $\quad$ Requested by consumers & 112 & 71.3 \\
\hline \multirow{8}{*}{ Source of Innovation Idea * } & - $\quad$ Leader/manager & 139 & 88.5 \\
\hline & $-\quad$ Staff & 126 & 80.3 \\
\hline & - $\quad$ Consumers & 75 & 47.8 \\
\hline & - $\quad$ Competitors & 98 & 62.4 \\
\hline & - $\quad$ Government & 47 & 29.9 \\
\hline & - $\quad$ University or research institution & 63 & 40.1 \\
\hline & - $\quad$ Social media & 99 & 63.1 \\
\hline & - $\quad$ Others & 32 & 20.4 \\
\hline
\end{tabular}

* Respondent may answer more than one option.

Regarding the innovation variable, all companies have made product and process innovations (see Table 3). The most common forms of sustainable innovation in process innovations are saving electricity $(100 \%)$ and avoiding plastics in services $(100 \%)$. Respondents in this study have many ways to minimize their electricity use, including designing a factory layout that allows more lighting from sunlight and the use of energy efficient lamps. Process improvements are also focused on reducing plastics and replacing them with more environmentally friendly ones. Meanwhile, in terms of product innovation, all respondents stated that their businesses are already using environmentally friendly packaging $(100 \%)$, and the new products they offer to consumers are generally free from hazardous food additives such as chemical additives (73.8\%).

Currently, there are many reasons for companies to perform sustainable innovation, such as government pressure. In this study, most food processing SMEs carried out sustainable innovation to protect the environment (92.4\%). Even so, there are also quite a significant number of SMEs that carry out sustainable innovation because of government encouragement $(77.1 \%)$. The local governments where the sample SMEs for this study operate have encouraged all companies to be more environmentally friendly, for example, by issuing stricter regulations regarding plastics. This could effectively influence food processing SMEs in Jakarta and its surroundings to carry out sustainable innovation. Previous studies $[20,22,24]$ have shown that internal motives (the desire to protect the environment) and external motives (government regulation) are pretty effective in influencing the adoption of green innovation product.

\subsection{Measurement Model}

It is necessary to perform a reliability test using Cronbach's alpha to measure the consistency and stability of the research instrument. The cut off point of Cronbach's alpha value is above 0.6. Table 4 shows that the smallest Cronbach's alpha value is 0.856 , which means that the measurement instrument is reliable. Furthermore, the measurement indicators of each variable can be confirmed as reliable if the value of the loading factor is greater than 0.7 [73,82]. In this study, the lowest loading factor is 0.759 ; therefore, all indicators are reliable. In addition, composite reliability (CR) in this study exceeded the threshold limit of 0.6 (see Table 4), as suggested by Hair et al. [73], which proves that there is an acceptable level of internal consistency and reliability. Lastly, convergent validity can be seen from the average variance extracted (AVE) value, higher than 0.50 for all factors. Table 5 shows that the shared variance of different variables is not higher than the square root of the average variance explained. Thus, the discriminant validity of the measurement model is accepted. Therefore, these findings confirmed that the measurement instruments could be used to measure the constructs in this study. 
Table 4. Measurement model testing.

\begin{tabular}{|c|c|c|c|c|}
\hline Variables & Loading Factor & AVE & Composite Reliability & Cronbach's Alpha \\
\hline $\begin{array}{l}\text { Leader's Support of Sustainable Innovation (LS) } \\
\text { - I motivate my employees to increase their environmental knowledge. } \\
\text { - } \quad \text { I support my employees to develop new products. } \\
\text { - } \quad \text { I am committed that my business develops eco friendly products. } \\
\text { I support my employees to be creative and innovative. }\end{array}$ & $\begin{array}{l}0.860 \\
0.857 \\
0.863 \\
0.868\end{array}$ & 0.762 & 0.822 & 0.899 \\
\hline $\begin{array}{l}\text { Employees' Innovation Potential Capability (EC) } \\
\text { My employees ... } \\
\text { - are interested and participate in developing new product ideas. } \\
\text { - } \quad \text { have environmental knowledge. } \\
\text { - } \quad \text { joinderstand processes of developing eco friendly products. } \\
\end{array}$ & $\begin{array}{l}0.858 \\
0.844 \\
0.867 \\
0.854 \\
0.859\end{array}$ & 0.801 & 0.862 & 0.903 \\
\hline $\begin{array}{l}\text { Organizational Innovation Culture (IC) } \\
\text { - My employees participate in problem-solving tasks. } \\
\text { - My employees are encouraged to share knowledge and ideas. } \\
\text { - My company provides rewards for employees who have ideas for new products and process improvements. } \\
\text { - My company facilitates space, equipment and materials for the development of new products. }\end{array}$ & $\begin{array}{l}0.874 \\
0.832 \\
0.844 \\
0.855 \\
0.848\end{array}$ & 0.823 & 0.766 & 0.942 \\
\hline $\begin{array}{l}\text { Organizational Sustainable Innovation (SI) } \\
\text { My business ... } \\
\text { - } \quad \text { develops new products that are environmentally friendly. } \\
\end{array}$ & $\begin{array}{l}0.864 \\
0.868 \\
\end{array}$ & 0.740 & 0.817 & 0.856 \\
\hline - develops innovations in production and service processes to reduces its negative impact on the environment. & 0.854 & & & \\
\hline $\begin{array}{l}\text { Business Sustainability (BS) } \\
\text { - } \quad \text { The sales volumes of my business increase. } \\
\text { - } \quad \text { Our customer satisfaction is high. } \\
\text { - } \quad \text { Our business profits increase. } \\
\text { - Our business operations empower the surrounding influence social wellbeing. } \\
\quad \text { operations avoid environmental damage. }\end{array}$ & $\begin{array}{l}0.865 \\
0.869 \\
0.765 \\
0.777 \\
0.788 \\
0.759\end{array}$ & 0.777 & 0.725 & 0.895 \\
\hline
\end{tabular}


Table 5. Correlation among constructs.

\begin{tabular}{cccccccc}
\hline Latent Variables & Mean & SD & RL & EC & IC & SI & BS \\
\hline Leader's support of sustainable innovation (LS) & 4.525 & 1.341 & 0.934 & & & & \\
Employees' innovation potential capability (EC) & 4.432 & 1.524 & 0.635 & 0.921 & & & \\
Organizational innovation culture (IC) & 4.751 & 1.276 & 0.588 & 0.526 & 0.873 & \\
Organizational sustainable innovation (SI) & 4.612 & 1.365 & 0.623 & 0.611 & 0.638 & 0.824 & \\
Business sustainability (BS) & 4.211 & 1.352 & 0.737 & 0.475 & 0.536 & 0.604 & 0.833 \\
\hline
\end{tabular}

Note: $\mathrm{N}=157$, squared roots of AVE extracted are shown in italics on the diagonal, and variable correlations are below the diagonal.

\subsection{Structural Model}

Before conducting hypothesis testing, it is crucial to analyze the goodness of fit indices, since this represents how well the model is. In SEM analysis, the goodness of fit test is carried out using several indices, such as RMSEA, NFI, IFI, TLI, and CFI.

Table 6 shows the value of goodness of fit, in which the majority values above the standard proposed. Therefore, the structural model in this study is developed within a good fit category.

Table 6. Goodness of fit.

\begin{tabular}{ccc}
\hline Indicators & Value & Recommended Value \\
\hline RMSEA & $0.058^{\mathrm{a}}$ & $\leq 0.08$ \\
CMIN/DF & $1.214^{\mathrm{a}}$ & $\leq 2.00$ \\
NFI & $0.915^{\mathrm{a}}$ & $\geq 0.90$ \\
IFI & $0.959^{\mathrm{a}}$ & $\geq 0.90$ \\
TLI & $0.840^{\mathrm{b}}$ & $\geq 0.90$ \\
CFI & $0.956^{\mathrm{a}}$ & $\geq 0.90$ \\
\hline
\end{tabular}

Note(s): ${ }^{a}$ Acceptability: acceptable; ${ }^{\mathrm{b}}$ Acceptability: marginal.

Table 7 shows the hypothesis testing. This study found that the leader's support of sustainable innovation has a significant influence on employees' innovation potential capability $(\beta=0.622, p<0.01)$ and organizational innovation culture $(\beta=0.485, p<0.05)$. Therefore, $\mathrm{H} 1$ and $\mathrm{H} 2$ were supported by this study. However, the leader's support has no significant direct impact on organizational sustainable innovation $(\beta=0.061, p>0.05)$; hence, hypothesis 3 was rejected. Moreover, the findings indicated that $43 \%$ of the variance in organizational sustainable innovation could be explained by employees' innovation potential capability $(\beta=0.421, p<0.01)$ and organizational innovation culture $(\beta=0.390$, $p<0.05)$. Hence, these results supported hypotheses 4 and 5 .

This study found that business sustainability was significantly affected by employees' innovation potential capability $(\beta=0.564, p<0.01)$, organizational innovation culture $(\beta=0.542, p<0.01)$, and organizational sustainable innovation $(\beta=0.411, p<0.05)$. Therefore, $\mathrm{H} 6, \mathrm{H} 7$ and $\mathrm{H} 8$ were supported. In addition, this study indicates that the model of organizational sustainable innovation can predict $64 \%$ of business sustainability.

Besides testing the direct effect of sustainable innovation and a business sustainability model, this study evaluates the indirect effect of a leader's support of sustainable innovation on organizational sustainable innovation and business sustainability. Hypothesis $3 a$ proposes that a leader's support of sustainable innovation indirectly affects sustainable innovation through employees' innovation potential capability; meanwhile, hypothesis $3 \mathrm{~b}$ posits that a leader's support affects sustainable innovation through organizational innovation culture.

The result found that a leader's support of sustainable innovation effects organizational sustainable innovation indirectly through employees' innovation potential capability $(\beta=0.261, p<0.05)$ and organizational innovation culture $(\beta=0.189, p<0.05)$. Consequently, this study accepts H3a and H3b. Furthermore, this study evaluates the indirect relationship between a leader's support of sustainable innovation and business sustainabil- 
ity through organizational sustainable innovation (H9a), employees' innovation potential capability $(\mathrm{H9b})$ and organizational innovation culture $(\mathrm{H} 9 \mathrm{c})$. The result found that a leader's support has a significant relationship with business sustainability through employees' innovation potential capability $(\beta=0.351, p<0.05)$ and organizational innovation culture $(\beta=0.263, p<0.05)$ indirectly. Meanwhile, the indirect relationship between a leader's support and business sustainability through organizational sustainable innovation is not significant $(\beta=0.025, p>0.05)$. Therefore, $\mathrm{H9b}$ and $\mathrm{H} 9 \mathrm{c}$ are verified by this study, while $\mathrm{H} 9 \mathrm{a}$ is rejected.

Table 7. Hypothesis testing.

\begin{tabular}{|c|c|c|c|}
\hline Hypotheses & $\beta$ & $p$-Values & Decision \\
\hline \multicolumn{4}{|l|}{ Direct Effect } \\
\hline $\mathrm{H} 1: \mathrm{LS} \rightarrow \mathrm{EC}$ & 0.622 & $* * *$ & Supported \\
\hline H2: LS $\rightarrow$ IC & 0.485 & $* *$ & Supported \\
\hline H3: LS $\rightarrow$ SI & 0.061 & 0.07 & Not Supported \\
\hline $\mathrm{H} 4: \mathrm{EC} \rightarrow \mathrm{SI}$ & 0.421 & $* *$ & Supported \\
\hline H5: IC $\rightarrow$ SI & 0.390 & $* *$ & Supported \\
\hline H6: $\mathrm{EC} \rightarrow \mathrm{BS}$ & 0.564 & $* * *$ & Supported \\
\hline $\mathrm{H7}: \mathrm{IC} \rightarrow \mathrm{BS}$ & 0.542 & $* * *$ & Supported \\
\hline H8: SI $\rightarrow$ BS & 0.411 & $* *$ & Supported \\
\hline \multicolumn{4}{|l|}{ Indirect Effect } \\
\hline H3a: LS $\rightarrow$ EC $\rightarrow$ SI & 0.261 & $* *$ & Supported \\
\hline $\mathrm{H} 3 \mathrm{~b}: \mathrm{LS} \rightarrow \mathrm{IC} \rightarrow \mathrm{SI}$ & 0.189 & $* *$ & Supported \\
\hline H9a: LS $\rightarrow$ SI $\rightarrow$ BS & 0.025 & & Not Supported \\
\hline $\mathrm{H} 9 \mathrm{~b}: \mathrm{LS} \rightarrow \mathrm{EC} \rightarrow \mathrm{BS}$ & 0.351 & $* *$ & Supported \\
\hline H9c: LS $\rightarrow$ IC $\rightarrow$ BS & 0.263 & $* *$ & Supported \\
\hline
\end{tabular}

\section{Discussion and Contribution}

\subsection{Discussion and Theoretical Contribution}

Research findings show that sustainable innovation in SMEs is determined by employees' innovation potential capability and organizational innovation culture. This result of the study does not support research conducted by Aboelmaged and Hashem [23], which concluded that there was no significant relationship between human capital and green innovation adoption. However, this study is in line with several previous studies that confirm the effect of employee capability on sustainable innovation [44,52]. Furthermore, this study also confirmed research conducted by Fiordelisi et al. [54], which found that organizational innovation culture has a vital role in sustainable innovation. Therefore, the organizational sustainable innovation model developed in this study is considered a robust model to explain sustainable innovation in the context of food processing SMEs.

This study also examined a leader's support in influencing employees' innovation potential capability and developing an organizational innovation culture. Thus, this study approves the body of knowledge explaining a leader's support in promoting culture innovation and supporting an employee to have capability to innovate $[45,46]$. These findings are significant, since they provide the first basic sustainable innovation model in food processing SMEs in an emerging market country. Other previous research assessing sustainable innovation explained determinant factors of sustainable innovation in a partial way [4], using large companies and conducted in the settings of developed countries [50].

This study rejected the direct relationship between a leader's support of sustainable innovation and organizational sustainable innovation. However, this does not mean that a leader's support of sustainable innovation has no relationship at all with influencing organizational sustainable innovation. This study demonstrates that a leader's support indirectly affects sustainable innovation through employee capability and innovation culture. Therefore, this study provides scientific evidence that to improve organizational 
sustainable innovation, the leaders of SMEs should improve organizational innovation culture and employee capability. Amjad et al. [63] mentioned that employee capability and performance could mediate between management and organizational sustainability.

Furthermore, this study evaluates the impact of an organizational sustainable innovation on business sustainability for food processing SMEs. It is important to explain the link between organizational sustainable innovation and business sustainability, particularly for food processing SMEs. As mentioned by Shashi et al. and Najib et al. [18,26], with the limited resources that SMEs have, applying sustainable innovation can be a burden. However, this study reveals that sustainable innovation has a positive influence on business sustainability. Therefore, this research finding may encourage food processing SMEs to implement organizational sustainable innovation. This study strengthened Smerecnik and Andersen [35], who argue that sustainable practice innovation will benefit business sustainability.

This study also confirms that employees' innovation potential capability positively influences the business sustainability of food processing SMEs. Therefore, this study notes the importance of employees' innovation potential capability for both organizational sustainable innovation and business sustainability. In line with Ullah et al. [60], this study found that employees who have environmental capability tend to contribute more to developing business sustainability. This study offers a new perspective on sustainability issues, particularly in food processing SMEs. Previous studies on sustainability focus on external factors, such as government regulation or social pressure, business opportunities from technological advances or customer demand for eco-friendly products [4,30]. Meanwhile, this study develops factors affecting sustainable innovation and business sustainability from the internal perspective, namely, a leader's support of sustainable innovation, employees' innovation potential capability and organizational innovation culture. For SMEs, the significant impact of sustainable innovation on business sustainability can be a source of motivation to practice organizational sustainable innovation. Further, this finding will change the mindset by considering sustainable innovation as an investment for the future of their business.

Regarding factors affecting business sustainability directly, this study presents that employees' innovation potential capability is the highest determinant factor of business sustainability. Meanwhile, employees' innovation potential capability is affected by the leader's support of sustainable innovation. Overall, by considering the direct and indirect effects of sustainability, the leader represents the highest determinant factor in the model of organizational sustainable innovation and business sustainability. Therefore, a leader's support in determining sustainable innovation and business sustainability is vital and unprecedented. Furthermore, this study found that a leader's support of sustainable innovation indirectly affects organizational sustainable innovation and business sustainability through employees' innovation potential capability and organizational innovation culture. Thus, this study strengthens the past studies about the role of leaders concerning employee capability and organizational innovation culture. Since the organizational structure in SMEs is typically a simple structure, the role of the leader becomes central in organizational sustainable innovation and business sustainability.

This study highlights three theoretical contributions. First, it provides a more robust model to predict organizational sustainable innovation and business sustainability in food processing SMEs. Second, this study also established the effect of a leader's support, organizational innovation culture and employees' innovation potential capability on organizational sustainable innovation and business sustainability, and empirically validates the existence of this relationship in the context of food processing SMEs in Indonesia as an emerging market country. Finally, to foster sustainable innovation practice in food processing SMEs, this study highlights the critical factor in increasing employees' innovation potential capability and promoting organizational innovation culture. The variable of employees' innovation potential capability and organizational innovation culture can mediate the relationship between a leader's support and organizational sustainable innovation. 


\subsection{Managerial Implication}

These findings provide a guideline for owners or managers of food processing SMEs to develop sustainable innovation and increase business sustainability. First, the owners or managers of food processing SMEs should evaluate their employees' innovation potential capability and how they can comply with the idea of sustainable innovation and business sustainability. The employee's mindset, knowledge, skill, and attitude should represent the capability needed to implement sustainable innovation and business sustainability. Second, in line with employee capability development, the owners or managers also should establish an organizational innovation culture in their business. Owners or managers can facilitate knowledge sharing traditions, the freedom to promote new ideas, learning together and so forth.

It is essential to establish sustainable innovation; however, this should be balanced with creating profit. This study notes that the sources of business sustainability come from organizational innovation culture, organizational sustainable innovation and employees' innovation potential capability. Therefore, SMEs' owners need to increase employee capability, establish an organizational innovation culture, and develop sustainable innovation, since those variables directly affect business sustainability. Increasing employee capability can be achieved, for example, by involving employees in specific training needed by their firm. It is believed that training is still an effective method to improve employees' innovation potential capability. However, some SMEs have a lack of budget to train their employees. Therefore, the role of the government in facilitating SMEs to improve their employees' innovation potential capability is crucial. Furthermore, since organizational sustainable innovation significantly impacts business sustainability, universities or other research institutions could be encouraged to help food processing SMEs become more innovative than before.

\subsection{Conclusion, Limitation and Future Research}

This study aims to develop organizational sustainable innovation and a business sustainability model from an internal organization sources perspective. The study found a positive and significant relationship between a leader's support of sustainable innovation, employees' innovation potential capabilities and organizational innovation culture. This shows that sustainable innovation is influenced by employees' innovation potential capabilities and organizational innovation culture directly and indirectly by the leader's support of sustainable innovation. This study also highlighted that business sustainability in food processing SMEs was directly affected by employees' innovation potential capability, organizational innovation culture and organizational sustainable innovation. In addition, the leader's support of sustainable innovation has an indirect effect on business sustainability through employees' innovation potential capability and organizational innovation culture. Overall, this study proved that the organizational sustainable innovation and business sustainability model could be applied to food processing SMEs, since the model of this study has high explanatory power. Therefore, it can be used to predict sustainable innovation and business sustainability in food processing SMEs in Indonesia and might be applied to other emerging market countries.

Although this study has succeeded in proving almost all of the hypotheses proposed, it still has several limitations that can be improved in future research. First, this study uses primary data, where data collection is carried out using a self-administered approach of interviews and observations on the selected sample. Future research would be better if it could be carried out using primary and secondary data from internal financial and sales company records and data from statistics agencies or the government. By using both types of data, the research model can be better validated. Second, this study only uses data from one sector, namely the food processing industry.

Further research can be enriched by collecting data from various industries so that this research model can be more generalizable. Second, other industries outside the food processing industry also need sustainable innovation and business sustainability. Third, 
this study proposes an integration model between sustainable innovation and business sustainability by developing several latent variables and observed variables. However, the constructs used in this study are limited to SMEs and can also be tested in large enterprises. Future studies can compare the application of sustainable innovation and business sustainability models between SMEs and large enterprises.

Author Contributions: Concept development, M.N., F.F. and A.A.; Methodology, M.N., F.F. and A.A.; Data Collection and analysis, M.N., F.F., P.P. and M.S.; Writing Draft Preparation, M.N., F.F., M.S., P.P. and R.R.; Editing, M.N., F.F., A.A., A.A.A.R. and D.S.; Supervision D.S. and A.A.A.R. All authors have read and agreed to the published version of the manuscript.

Funding: This research received no external funding.

Institutional Review Board Statement: Not Applicable.

Informed Consent Statement: Not Applicable.

Data Availability Statement: Not Applicable.

Conflicts of Interest: The authors declare no conflict of interest.

\section{References}

1. Distanont, A.; Khongmalai, O. The Role of Innovation in Creating a Competitive Advantage. Kasetsart J. Soc. Sci. 2020, 41, 15-21. [CrossRef]

2. Unruh, G.; Kiron, D.; Kruschwitz, N.; Reeves, M.; Rubel, H.; Felde, A.M.Z. "Investing for a Sustainable Future," MIT Sloan Management Review. May 2016. Available online: http:/ / www.truevaluemetrics.org/DBpdfs/ImpactInvesting/MITSMR-BCGInvesting-for-a-Sustainable-Future-2016.pdf (accessed on 10 October 2021).

3. Najib, M.; Kiminami, A. Competitive Strategy and Business Performance of Small and Medium Enterprises in the Indonesian Food Processing Industry. Stud. Reg. Sci. 2011, 41, 315-330. [CrossRef]

4. Cillo, V.; Petruzzelli, A.M.; Ardito, L.; Giudice, M.D. Understanding Sustainable Innovation: A Systematic Literature Review. Corp. Soc. Responsib. Environ. Manag. 2019, 26, 1012-1025. [CrossRef]

5. Wang, Y.; Yang, Y. Analyzing the Green Innovation Practices Based on Sustainability Performance Indicators: A Chinese Manufacturing Industry Case. Environ. Sci. Pollut. Res. 2020, 28, 1181-1203. [CrossRef]

6. Bansal, P.; DesJardine, M.R. Business Sustainability: It is About Time. Strateg. Organ. 2014, 12, 70-78. [CrossRef]

7. Lopes de Sousa Jabbour, A.B.; Ndubisi, N.O.; Roman Pais Seles, B.M. Sustainable Development in Asian Manufacturing SMEs: Progress and Directions. Int. J. Prod. Econ. 2020, 225, 107567. [CrossRef]

8. Rencana Strategis Kementerian Koperasi dan Usaha Kecil dan Menengah Tahun 2020-2024. Available online: https: / / kemenkopukm.go.id/uploads/laporan/1602751704_Permen\%20KUKM\%20Nomor\%205\%20Tahun\%202020\%20tentang\%20 Renstra\%20Kementerian\%20Koperasi\%20dan\%20UKM\%20Tahun\%202020-2024.pdf (accessed on 10 October 2021).

9. Nigri, G.; Del Baldo, M. Sustainability Reporting and Performance Measurement Systems: How do Small- and Medium-Sized Benefit Corporations Manage Integration? Sustainability 2018, 10, 4499. [CrossRef]

10. Salzberg, A.C.; Gough, M.Z.; Suen, I.S. Sustainable Innovation Behavior in Restaurants. J. Foodserv. Bus. Res. 2019, 22, 167-190. [CrossRef]

11. Tevapitak, K.; Helmsing, A.H.J. The Interaction between Local Governments and Stakeholders in Environmental Management: The Case of Water Pollution by SMEs in Thailand. J. Environ. Manag. 2019, 247, 840-848. [CrossRef]

12. Van Dyk, J.S.; Gama, R.; Morrison, D.; Swart, S.; Pletschke, B.I. Food Processing Waste: Problems, Current Management and Prospects for Utilizing the Lignocellulose Component through Enzyme Synergistic Degradation. Renew. Sustain. Energy Rev. 2013, 26, 521-531. [CrossRef]

13. Lewis, K.V.; Cassells, S.; Roxas, H. SMEs and the Potential for A Collaborative Path to Environmental Responsibility. Bus. Strategy Environ. 2015, 24, 750-764. [CrossRef]

14. Redmond, J.; Cox, J.W.; Curtis, J.; Kirk-Brown, A.; Walker, B. Beyond Business as Usual: How (and why) the Habit Discontinuity Hypothesis Can Inform SME Engagement in Environmental Sustainability Practices. Australas. J. Environ. Manag. 2016, 23, 426-442. [CrossRef]

15. Koirala, S. SMEs: Key Drivers of Green and Inclusive Growth. Inclusive Solutions for the Green Transition, OECD 2018. Available online: https:/ / www.oecd.org/greengrowth/GGSD_2018_SME\%20Issue\%20Paper_WEB.pdf (accessed on 1 September 2021).

16. Eijdenberg, E.L.; Sabokwigina, D.; Masurel, E. Performance and Environmental Sustainability Orientations in the Informal Economy of a Least Developed Country. Int. J. Entrep. Behav. Res. 2019, 25, 129-149. [CrossRef]

17. Najib, M.; Widyastuti, H.; Andrianto, M.S.; Septiani, S.; Fahma, F. Market Orientation and Service Quality as Driving Forces of Business Sustainability: Evidence from Small Coffee Shop. Acad. Strategy Manag. J. 2020, 19, 1-8.

18. Roxas, B.; Ashill, N.; Chadee, D. Effects of Entrepreneurial and Environmental Sustainability Orientations on Firm Performance: A Study of Small Businesses in the Philippines. J. Small Bus. Manag. 2017, 55, 163-178. [CrossRef] 
19. Shashi, S.; Cerchione, R.; Centobelli, P.; Shabani, A. Sustainability Orientation, Supply Chain Integration, and SMEs Performance: A Causal Analysis. Benchmarking Int. J. 2018, 25, 3679-3701. [CrossRef]

20. Leonidou, L.C.; Christodoulides, P.; Kyrgidou, L.P.; Palihawadana, D. Internal Drivers and Performance Consequences of Small Firm Green Business Strategy: The Moderating Role of External Forces. J. Bus. Ethics 2017, 140, 585-606. [CrossRef]

21. Kneipp, J.M.; Gomes, C.M.; Bichueti, R.S.; Frizzo, K.; Perlin, A.P. Sustainable innovation practices and their relationship with the performance of industrial companies. Rev. Gestão 2019, 26, 94-111. [CrossRef]

22. Prasetya, P.; Najib, M.; Soehadi, A.W. How to Measure Relationship Value in Principal-Retailer Context. J. Distrib. Sci. 2021, 19, 37-47.

23. Aboelmaged, M.; Hashem, G. Absorptive Capacity and Green Innovation Adoption in SMEs: The Mediating Effects of Sustainable Organizational Capabilities. J. Clean. Prod. 2019, 20, 853-863. [CrossRef]

24. Najib, M.; Ermawati, W.J.; Fahma, F.; Endri, E.; Suhartanto, D. Fintech in the Small Food Business and Its Relation with Open Innovation. J. Open Innov. Technol. Mark. Complex. 2021, 7, 88. [CrossRef]

25. Albort-Morant, G.; Leal-Rodríguez, A.L.; De Marchi, V. Absorptive Capacity and Relationship Learning Mechanisms as Complementary Drivers of Green Innovation Performance. J. Knowl. Manag. 2018, 22, 432-452. [CrossRef]

26. Subramony, M.; Segers, J.; Chadwick, C.; Shyamsunder, A. Leadership Development Practice Bundles and Organizational Performance: The Mediating Role of Human Capital and Social Capital. J. Bus. Res. 2018, 83, 120-129. [CrossRef]

27. Sun, X.; Li, H.; Ghosal, V. Firm-Level Human Capital and Innovation: Evidence from China. China Econ. Rev. 2020, 59 , 101388. [CrossRef]

28. Iqbal, Q.; Ahmad, H.N.; Li, Y. Sustainable Leadership in Frontier Asia Region: Managerial Discretion and Environmental Innovation. Sustainability 2021, 13, 5002. [CrossRef]

29. Najib, M.; Septiani, S.; Nurlaela, S. The Role of Innovation, Entrepreneurial Self-Efficacy and Local Uniqueness on Marketing Performance in Small and Medium-Sized Restaurants. J. Foodserv. Bus. Res. 2020, 23, 499-519. [CrossRef]

30. Tello, S.F.; Yoon, E. Examining Drivers of Sustainable Innovation. Int. J. Bus. Strategy 2008, 8, 164-169.

31. Schiederig, T.; Tietze, F; Herstatt, C. Green Innovation in Technology and Innovation Management-An Exploratory Literature Review. RED Manag. 2012, 42, 180-192.

32. Wang, Y.Z.; Lo, F.Y.; Weng, S.M. Family Businesses Successors Knowledge and Willingness on Sustainable Innovation: The Moderating Role of Leader's Approval. J. Innov. Knowl. 2019, 4, 188-195. [CrossRef]

33. Najib, M.; Sumarwan, U.; Septiani, S.; Waibel, H.; Suhartanto, D.; Fahma, F. Individual and Socio-Cultural Factors as Driving Forces of the Purchase Intention for Organic Food by Middle Class Consumers in Indonesia. J. Int. Food Agribus. Mark. 2021, 1-12. [CrossRef]

34. Najib, M.; Abdul Rahman, A.A.; Fahma, F. Business Survival of Small and Medium-Sized Restaurants through a Crisis: The Role of Government Support and Innovation. Sustainability 2021, 13, 10535. [CrossRef]

35. Smerecnik, K.R.; Andersen, P.A. The diffusion of Environmental Sustainability Innovations in North American Hotels and Ski Resorts. J. Sustain. Tour. 2011, 19, 171-196. [CrossRef]

36. Barney, J. Firm Resources and Sustained Competitive Advantage. J. Manag. 1991, 17, 99-120. [CrossRef]

37. Teece, D.J.; Pisano, G.; Shuen, A. Dynamic Capabilities and Strategic Management. Strateg. Manag. J. 1997, 18, 509-533. [CrossRef]

38. Najib, M.; Kiminami, A. Innovation, Cooperation and Business Performance: Some Evidence from Indonesian Small Food Processing Cluster. J. Agribus. Dev. Emerg. Econ. 2011, 1, 75-96. [CrossRef]

39. Kuntadi, A.; Sumarwan, U.; Najib, M.; Jahroh, S. The Effects of Gender and Tenure on the Relationship between Decision-Makers' Behavioral Preferences and University's Innovations Adoption. Manag. Sci. Lett. 2020, 10, 3445-3452. [CrossRef]

40. Del Giudice, M.; Khan, Z.; De Silva, M.; Scuotto, V.; Caputo, F.; Carayannis, E. The Micro-Level Actions Undertaken by Owner-Managers in Improving the Sustainability Practices of Cultural and Creative Small and Medium Enterprises: A United Kingdom-Italy Comparison. J. Organ. Behav. 2017, 38, 1396-1414. [CrossRef]

41. Vrontis, D.; Bresciani, S.; Giacosa, E. Tradition and Innovation in Italian Wine Family Businesses. Br. Food J. 2016, $118,1883-1897$. [CrossRef]

42. Waite, A.M. Leadership's Influence on Innovation and Sustainability. Eur. J. Train. Dev. 2014, 38, 15-39. [CrossRef]

43. Le, P.B.; Lei, H. Determinants of Innovation Capability: The Roles of Transformational Leadership, Knowledge Sharing and Perceived Organizational Support. J. Knowl. Manag. 2019, 23, 527-547. [CrossRef]

44. Subramanian, D.; Zimmermann, B. Voice in French Corporate Training: A Critical Issue in Developing Employee Capability. Econ. Ind. Democr. 2020, 41, 296-322. [CrossRef]

45. Kremer, H.; Villamor, I.; Aguinis, H. Innovation Leadership: Best-Practice Recommendations for Promoting Employee Creativity, Voice, and Knowledge Sharing. Bus. Horiz. 2019, 62, 65-74. [CrossRef]

46. Yang, Z.; Nguyen, V.T.; Le, P.B. Knowledge Sharing Serves as a Mediator between Collaborative Culture and Innovation Capability: An Empirical Research. J. Bus. Ind. Mark. 2018, 33, 958-969. [CrossRef]

47. El Harbi, S.; Anderson, A.R.; Amamou, M. Innovation Culture in Small Tunisian ICT Firms. J. Small Bus. Enterp. Dev. 2014, 21, 132-151. [CrossRef]

48. do Adro, F.J.N.; Leitão, J.C.C. Leadership and Organizational Innovation in the Third Sector: A Systematic Literature Review. Int J. Innov. Stud. 2020, 4, 51-67. [CrossRef] 
49. Kesting, P.; Ulhøi, J.P. Employee-Driven Innovation: Extending the License to Foster Innovation. Manag. Decis. 2010, 48, 65-84. [CrossRef]

50. Hanifah, H.; Halim, H.A.; Ahmad, N.H.; Vafaei-Zadeh, A. Can Internal Factors Improve Innovation Performance via Innovation Culture in SMEs? Benchmarking 2019, 27, 382-405. [CrossRef]

51. Wei, Y.; Kang, D.; Wang, Y. Geography, Culture, and Corporate Innovation. Pac. Basin Financ. J. 2019, 56, 310-329. [CrossRef]

52. Lei, H.; Nguyen, T.T.; Le, P.B. How Knowledge Sharing Connects Interpersonal Trust and Innovation Capability: The Moderating Effect of Leadership Support. Chin. Manag. Stud. 2019, 13, 276-298. [CrossRef]

53. Kianto, A.; Sáenz, J.; Nekane, A. Knowledge-based human resource management practices, intellectual capital and innovation. J. Bus. Res. 2017, 81, 11-20. [CrossRef]

54. Fiordelisi, F.; Renneboog, L.; Ricci, O.; Lopes, S.S. Creative corporate culture and innovation. J. Int. Financ. Mark. Inst. Money 2019, 63, 101137. [CrossRef]

55. Michaelis, T.L.; Aladin, R.; Pollack, J.M. Innovation Culture and the Performance of New Product Launches: A Global Study. J. Bus. Ventur. Insights 2018, 9, 116-127. [CrossRef]

56. Higgins, J.M.; Mc Allastar, C. Want Innovation? Then Use Cultural Artefacts that support it. Organ. Dyn. 2002, 31, 74-85. [CrossRef]

57. Gross-Gołacka, E.; Kusterka-Jefmańska, M.; Jefmański, B. Can Elements of Intellectual Capital Improve Business Sustainability?-The Perspective of Managers of SMEs in Poland. Sustainability 2020, 12, 1545. [CrossRef]

58. Jang, H.-W.; Lee, S.-B. Serving Robots: Management and Applications for Restaurant Business Sustainability. Sustainability 2020, 12, 3998. [CrossRef]

59. Najib, M.; Fahma, F. Investigating the Adoption of Digital Payment System through an Extended Technology Acceptance Model: An Insight from the Indonesian Small and Medium Enterprises. Int. J. Adv. Sci. Eng. Inf. Technol. 2020, 10, 1702-1708. [CrossRef]

60. Ullah, H.; Wang, Z.; Bashir, S.; Khan, A.R.; Riaz, M.; Syed, N. Nexus between IT Capability and Green Intellectual Capital on Sustainable Businesses: Evidence from Emerging Economies. Environ. Sci. Pollut. Res. 2021, 28, 27825-27843. [CrossRef] [PubMed]

61. Bag, S.; Gupta, S. Examining the Effect of Green Human Capital Availability in Adoption of Reverse Logistics and Remanufacturing Operations Performance. Int. J. Manpow. 2020, 41, 1097-1117. [CrossRef]

62. Iqbal, Q. The Era of Environmental Sustainability: Ensuring That Sustainability Stands on Human Resource Management. Glob. Bus. Rev. 2020, 21, 377-391. [CrossRef]

63. Amjad, F.; Abbas, W.; Zia-UR-Rehman, M. Effect of Green Human Resource Management Practices on Organizational Sustainability: The Mediating Role of Environmental and Employee Performance. Environ. Sci. Pollut. Res. 2021, 28, 28191-28206. [CrossRef]

64. Zhen, Z.; Yousaf, Z.; Radulescu, M.; Yasir, M. Nexus of Digital Organizational Culture, Capabilities, Organizational Readiness, and Innovation: Investigation of SMEs Operating in the Digital Economy. Sustainability 2021, 13, 720. [CrossRef]

65. Fazlığlu, B.; Dalgıç, B.; Yereli, A.B. The Effect of Innovation on Productivity: Evidence from Turkish Manufacturing Firms. Ind. Innov. 2019, 26, 439-460. [CrossRef]

66. Boons, F.; Montalvo, C.; Quist, J.; Wagner, M. Sustainable Innovation, Business Models and Economic Performance: An Overview. J. Clean. Prod. 2013, 45, 1-8. [CrossRef]

67. Provasnek, A.K.; Schmid, E.; Geissler, B.; Steiner, G. Sustainable Corporate Entrepreneurship: Performance and Strategies toward Innovation. Bus. Strategy Environ. 2017, 26, 521-535. [CrossRef]

68. Borsatto, J.M.L.S.; Bazani, C.L. Green Innovation and Environmental Regulations: A Systematic Review of International Academic Works. Res. Environ. Plan. Manag. 2020, 28, 63751-63768. [CrossRef]

69. Tandra, H.; Suroso, A.I.; Najib, M.; Syaukat, Y. The Effect of Covid-19 in European Union on the Performance of Indonesian Publicly Listed Palm Oil Companies. Accounting 2021, 7, 801-808. [CrossRef]

70. Suroso, A.I.; Tandra, H.; Syaukat, Y.; Najib, M. The Issue in Indonesian Palm Oil Stock Decision Making: Sustainable and Risk Criteria. Decis. Sci. Lett. 2021, 10, 241-246. [CrossRef]

71. Borghesi, S.; Cainelli, G.; Mazzanti, M. Linking Emission Trading to Environmental Innovation: Evidence from the Italian Manufacturing Industry. Res. Policy 2015, 44, 669-683. [CrossRef]

72. Iqbal, Q.; Ahmad, N.H.; Halim, H.A. How Does Sustainable Leadership Influence Sustainable Performance? Empirical Evidence from Selected ASEAN Countries. SAGE Open 2020, 10, 1-16. [CrossRef]

73. Hair, J.F., Jr.; Matthews, L.M.; Matthews, R.L.; Sarstedt, M. PLS-SEM or CB-SEM: Updated Guidelines on which Method to Use. Int. J. Multivar. Data Anal. 2017, 1, 107-123. [CrossRef]

74. Kartika, T.; Firdaus, A.; Najib, M. Contrasting the Drivers of Customer Loyalty; Financing and Depositor Customer, Single and Dual Customer, in Indonesian Islamic bank. J. Islamic Mark. 2020, 11, 933-959. [CrossRef]

75. Saiyed, A.A.M. The Role of Leadership in Business Model Innovation: A Case of an Entrepreneurial Firm from India. N. Engl. J. Entrep. 2019, 22, 70-88. [CrossRef]

76. Burcharth, A.; Præst Knudsen, M.; Søndergaard, H.A. The Role of Employee Autonomy for Open Innovation Performance. Bus. Process. Manag. J. 2017, 23, 1245-1269. [CrossRef]

77. Costa, R.V.; Fernández-Jardon Fernández, C.; Figueroa Dorrego, P. Critical Elements for Product Innovation at Portuguese Innovative SMEs: An Intellectual Capital Perspective. Knowl. Manag. Res. Pract. 2014, 12, 322-338. [CrossRef] 
78. Dobni, C.B. Measuring Innovation Culture in Organizations: The Development of a Generalized Innovation Culture Construct Using Exploratory Factor Analysis. Eur. J. Innov. Manag. 2008, 11, 539-559. [CrossRef]

79. Dombrowski, C.; Kim, J.Y.; Desouza, K.C.; Braganza, A.; Papagari, S.; Baloh, P.; Jha, S. Elements of Innovative Cultures. Knowl. Process. Manag. 2007, 14, 190-202. [CrossRef]

80. Kamboj, S.; Rahman, Z. Market Orientation, Marketing Capabilities and Sustainable Innovation: The Mediating Role of Sustainable Consumption and Competitive Advantage. Manag. Res. Rev. 2017, 40, 698-724. [CrossRef]

81. Higdon, B. Strategies Independent Coffee Shop Owners Require to Survive beyond Five Years. Ph.D. Thesis, Walden University, Washington, DC, USA, 2016.

82. Nurlaela, S.; Sumarwan, U.; Najib, M. Determinants of Online Journey and Its Influence on Online Customer Satisfaction Associated with Online Customer Loyalty. Int. J. Electron. Mark. Retail. 2019, 10, 230-243. [CrossRef] 